https://ojs.umrah.ac.id/index.php/anugerah

\title{
Edukasi New Normal, Cuci Tangan Pakai Sabun, dan Penggunaan Masker di Lingkungan Sekolah Menggunakan Video Learning
}

\author{
Rita Fitriani $^{1}$, Inelda Yulita ${ }^{2 *}$, Fitriah Khoirunnisa ${ }^{3}, \&$ Ardi Widhia Sabekti ${ }^{4}$ \\ 1, 2, 3,4Universitas Maritim Raja Ali Haji, Tanjungpinang, Kepulauan Riau 29115, Indonesia \\ "e-mail korespondensi: inelda_chem@umrah.ac.id
}

Pengiriman: 31 Oktober 2021; Diterima: 5 November 2021; Publikasi: 30 November 2021

DOI: https://doi.org/10.31629/anugerah.v3i2.3868

\begin{abstract}
Abstrak
Dunia Pendidikan harus beradaptasi dengan kehidupan saat New Normal. Sekolah yang akan melaksanakan pembelajaran tatap muka harus mempersiapkan diri dengan baik. Jika pembelajaran tatap muka dilaksanakan maka protokol kesehatan 5M (Mencuci tangan, menjaga jarak, memakai masker, mengurangi mobilitas, dan menjauhi kerumunan) yang ketat harus dilaksanakan. Demi menyikapi hal ini perlu diadakan program edukasi Cuci Tangan Pakai Sabun (CTPS) dan penggunaan masker yang baik dan benar melalui Video Learning. Kegiatan Edukasi New Normal ini dilakukan di Lingkungan Sekolah SD Negeri 001 Teluk Sebong Kabupaten Bintan dengan peserta, berasal dari siswa, guru, kepala sekolah, dan penjaga sekolah. Kegiatan edukasi berjalan dengan lancar dan tanpa hambatan serta respons civitas sekolah yang antusias. Setelah kegiatan edukasi dilakukan, diperoleh hasil bahwa tingkat pemahaman tertinggi peserta kegiatan edukasi yaitu tentang protokol kesehatan 5M sebesar 94,95\%.
\end{abstract}

Kata kunci: edukasi; video learning; new normal; CTPS; masker

\begin{abstract}
The world of education must adapt to life during the New Normal. Schools that will carry out face-to-face learning must prepare themselves well. If face-to-face learning is carried out, strict $5 M$ health protocols (washing hands, maintaining distance, wearing masks, reducing mobility, and staying away from crowds) must be implemented. To address this, it is necessary to hold an educational program for Hand Washing with Soap (CTPS) and proper use of masks through Video Learning. This New Normal Educational activity was carried out in the SD Negeri 001 Teluk Sebong School environment, Bintan Regency with participants, from students, teachers, principals, and school guards. Educational activities ran smoothly and without a hitch as well as enthusiastic responses from the school community. After the educational activity was carried out, it was found that the highest level of understanding of the participants in the education activity was about the 5 M health protocol, which was $94.95 \%$.
\end{abstract}

Keywords: education; video learning; new normal; CTPS; masks

\section{Pendahuluan}

Coronavirus Disease 2019 (Covid-19) adalah penyakit menular yang disebabkan oleh Severe Acute Respiratory Syndrome Coronavirus 2 (SARS-CoV-2). Infeksi Covid-19 ditandai dengan gejala gangguan pernapasan akut seperti batuk, demam, dan sesak napas. Masa inkubasi rata-rata 5-6 hari dan masa inkubasi terpanjang yakni 14 hari. Pada kasus Covid-19 berat bisa menyebabkan pneumonia, sindrom pernapasan akut, 


\section{JURNAL ANUGERAH, November 2021; 3(2): 87-98 e-ISSN 2715-8179}

gagal ginjal, dan bahkan kematian (Kemenkes RI, 2020). Saat ini pandemi Covid-19 belum berakhir, bahkan Organisasi Kesehatan Dunia (WHO) menyatakan bahwa pandemi tidak akan segera berakhir. Untuk itu, masyarakat dunia harus siap beradaptasi dan terbiasa hidup berdampingan dengan Covid-19. Cara baru untuk bertahan hidup dengan meningkatnya jumlah korban pandemi Covid-19 dikenal dengan New Normal. New Normal adalah kebijakan pemerintah yang dimaknai sebagai perubahan perilaku masyarakat untuk tetap menjalankan aktivitas secara normal dan sebagai scenario untuk mempercepat penanganan Covid-19 dalam aspek kesehatan dan sosial ekonomi (Jacobis et al., 2021).

Cara hidup baru ini juga diterapkan dalam proses pembelajaran di sekolah. Adaptasi pola pembelajaran di kehidupan New Normal membuat semua pihak bersama-sama mempersiapkan diri. Semua sekolah mulai mempersiapkan diri untuk penerapan pendidikan di New Normal. Jika sekiranya diperlukan pembelajaran tatap muka, tentunya prosedur protokol kesehatan yang ketat harus diikuti. Salah satu sekolah yang melanjutkan pembelajaran di New Normal adalah SDN 001 Teluk Sebong Kabupaten Bintan. Sekolah memulai pembelajaran di New Normal dengan siswa tetap datang ke sekolah untuk belajar. Pembelajaran pun sudah dimulai seperti biasa. Namun yang berbeda adalah sekolah memfasilitasi sabun dan tempat cuci tangan di sekolah. Berdasarkan wawancara dengan kepala sekolah, belum ada edukasi langsung terhadap siswa maupun civitas lainnya mengenai cuci tangan atau pemakaian masker yang benar. Sebelumnya sudah ada pihak puskesmas datang untuk memberikan penyuluhan, namun hanya sekali dan pemaparannya bersifat umum. Hal ini disebabkan jarak sekolah yang terlalu jauh. Di mana sekolah ini termasuk sekolah di daerah 3T (Tertinggal, Terjauh, dan Terluar).

Sebagaimana yang telah dijelaskan sebelumnya penting dilakukan edukasi Cuci Tangan Pakai Sabun (CTPS) dan penggunaan masker yang benar, sehingga civitas sekolah mengetahui dan memahami bagaimana adaptasi kebiasaan baru di New Normal dalam dunia pendidikan. Edukasi yang dilakukan bukan hanya berupa petunjuk penggunaan atau pemakaian, namun penyampaian konsep sains dibalik aturan yang ada. Hal ini seiring dengan apa yang dilakukan dalam kegiatan pengabdian oleh Nugroho et al. (2020) mengenai kegiatan sosialisasi, penyuluhan, pelatihan dan pendampingan dengan baik, terhadap masyarakat terhadap kesiapan adaptasi kebiasaan baru pencegahan penularan Covid-19. Selain itu juga terkait dengan kegiatan pengabdian yang dilakukan Lubis et al. (2020) tentang gerakan desa sadar bahaya Covid-19. Sehingga nantinya melalui kegiatan pengabdian ini, civitas sekolah memahami alasan mengapa harus CTPS dengan baik dan benar, serta mengapa harus memakai masker dengan baik dan benar.

Agar edukasi dapat berjalan dengan optimal, maka digunakan metode Video Learning pada kegiatan pengabdian. Alasan penggunaannya adalah karena Video Learning lebih efektif dan efisien dalam menyampaikan suatu informasi dalam waktu singkat, didukung desain grafis yang menarik bagi siswa SD sebagai subjek sasaran pengabdian, selama informasinya masih relevan Video Learning dapat diakses kapan pun dan dimana pun, mampu merangsang keterlibatan indera sehingga akan membuat siswa lebih mudah memahami informasi yang disampaikan, khususnya konsep sains sederhana. Video Learning ini disajikan di awal sesi pengabdian.

Video Learning menyajikan ilustrasi kehidupan New Normal yang dijalani saat ini. Pada video dijelaskan bahwa dari sudut pandang agama, dengan mengambil kutipan dari Al quran surat Ath Taubah ayat 51, dapat dipahami bahwa semua kejadian tidak lepas dari kehendak Allah SWT, maka Allah SWT jugalah yang akan menjadi penolong umat manusia. Selanjutnya konsep sains dalam aturan CTPS dijelaskan mencuci tangan tidak cukup dengan menggunakan air bersih saja namun diperlukan juga sabun. Sabun mengandung senyawa lemak yang disebut Amphiphiles. Amphiphiles serupa dengan lipid pada membran virus. Saat sabun bersentuhan dengan lipid dalam membran virus, sabun mengikatnya dan menyebabkannya terlepas dari virus, selanjutnya virus terlepas dari kulit (Lestari et al., 2020). Mencuci tangan tanpa menggunakan sabun menyebabkan kotoran dan kuman penyakit, salah satunya virus, masih tertinggal di tangan. Alasan penggunaan 
masker yang baik dan benar dianalogikan dengan alat penyaring debu. Jika semakin rapat pori penyaringnya maka semakin banyak pula debu yang tersaring, dan sebaliknya. Penggunaan masker jenis apapun tidak akan memengaruhi efisiensi penyaringannya, seberapa bagus segelnya, serta akan memiliki efek minimum jika tidak digunakan bersamaan dengan upaya pencegahan lainnya (Silva, 2020).

Pengabdian diakhiri dengan sesi siswa SD melakukan praktik CTPS secara bergantian dan penggunaan masker dengan baik dan benar. Praktik ini dibimbing langsung oleh tim Pengabdian Kepada Masyarakat Unggulan Prodi (PKMUP). Diharapkan dengan adanya pengabdian ini, civitas sekolah khususnya siswa SD teredukasi mengenai kehidupan New Normal dari segi sains.

\section{Metode}

Kegiatan pengabdian dilaksanakan di sekolah yang telah menerapkan pembelajaran New Normal yakni di SDN 001 Teluk Sebong Kabupaten Bintan pada Selasa 28 September 2021. Kegiatan pengabdian ini dilakukan dengan melakukan edukasi langsung melalui Video Learning pada civitas sekolah, baik siswa, guru, kepala sekolah, maupun penjaga sekolah, dengan jumlah peserta kegiatan pengabdian adalah 22 orang. Tahapan kegiatan pengabdian dijelaskan sebagai berikut :

1. Melakukan kunjungan untuk menetapkan sekolah yang mengadaptasi kebiasaan belajar New Normal.

2. Melakukan kajian literatur mengenai video edukasi learning mengenai CTPS dan penggunaan masker yang baik dan benar.

3. Pembuatan materi edukasi.

4. Edukasi kebiasaan New Normal di sekolah.

Evaluasi keberhasilan kegiatan ini menggunakan kuesioner terbuka mengenai CTPS, kebiasaan New Normal, dan penggunaan masker yang benar. Indikator keberhasilan dilihat dari pengetahuan dan pemahaman peserta melalui evaluasi yang diberikan. Kuesioner disusun berdasarkan indikator-indikator yang dapat mengukur pemahaman peserta. Kuesioner ini diberikan kepada peserta setelah kegiatan edukasi CTPS, kebiasaan New Normal, dan penggunaan masker selesai dilaksanakan. Setelah pengumpulan data dengan kuesioner, selanjutnya dilakukan reduksi data, pengkodean, dan analisis data kuesioner yang bersifat kuantitatif dianalisis dengan menggunakan rumus persentase berikut:

$$
P t=\frac{X}{Y} \times 100 \% \quad \text { (Sudijono, 2010) }
$$

Keterangan :

$\mathrm{Pt}=$ Persentase siswa yang tidak menjawab untuk tiap butir soal

$\mathrm{X}=$ Frekuensi siswa yang tidak menjawab untuk tiap soal

$\mathrm{Y}=$ Jumlah total sampel penelitian

Selanjutnya, pengelompokkan tingkat pemahaman berdasarkan kriteria sebagai berikut :

Tabel 1

Skala Tingkat Pemahaman

\begin{tabular}{cc}
\hline Tingkat Pemahaman & Persentase Jumlah Yang Menjawab Benar \\
\hline Tinggi & $76 \%-100 \%$ \\
Sedang & $60 \%-75 \%$ \\
Rendah & $0 \%-59 \%$ \\
\hline
\end{tabular}




\section{Hasil dan Pembahasan}

Kegiatan pengabdian ini memiliki tema "Edukasi New Normal, CTPS, dan Penggunaan Masker Melalui Video Learning di Lingkungan Sekolah SD Negeri 001 Teluk Sebong Kabupaten Bintan”. Kegiatan ini dilakukan dengan melakukan edukasi langsung kepada civitas sekolah SD Negeri 001 Teluk Sebong Kabupaten Bintan, baik siswa, guru, kepala sekolah, maupun penjaga sekolah melalui Video Learning.

Adapun tahapan kegiatan pengabdian yang dilakukan adalah:

\section{Melakukan Kunjungan Ke SD Negeri 001 Teluk Sebong}

Adapun kunjungan ini bermaksud untuk mendapatkan izin dan persetujuan pihak sekolah terhadap kegiatan pengabdian yang dilakukan. Pada saat kunjungan, tim yang berkunjung terdiri dari ketua tim dan 2 orang mahasiswa, sebagaimana ditampilkan pada Gambar 1. Tim pengabdian bertemu langsung dengan Kepala SD Negeri 001 Teluk Sebong, yaitu Bapak Haryanto, S.Pd.SD.

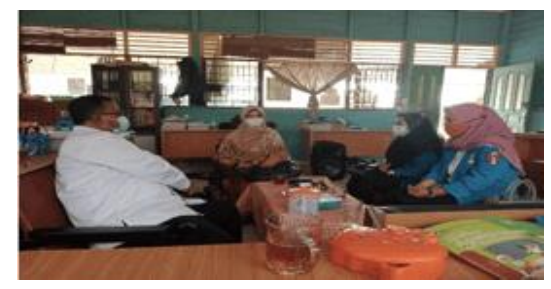

Gambar 1. Kunjungan dengan kepala sekolah SD Negeri 001 Teluk Sebong

\section{Melakukan Kajian Literatur Mengenai Video Edukasi Learning Mengenai CTPS Dan Penggunaan Masker Yang Baik dan Benar}

Kajian literatur mengenai CTPS, penggunaan masker, dan New Normal diambil dari surat edaran Kemenkes RI dan Gerakan Masyarakat Hidup Sehat (Germas), dan UNICEF. CTPS efektif mencegah penularan virus karena tangan yang bersih setelah dicuci pakai sabun dapat mengurangi risiko masuknya virus ke dalam tubuh. Mencuci tangan dengan air saja tidaklah cukup untuk mematikan kuman penyebab penyakit. CTPS dan dengan air bersih mengalir adalah suatu cara mudah untuk melindungi diri dari penyakit menular, termasuk Covid-19. Selanjutnya, CTPS selama 40-60 detik serta mengikuti langkah yang disarankan terbukti efektif mematikan kuman penyakit. CTPS dapat efektif bila tersedia sarana CTPS, dilakukan pada waktu tertentu, dan dilakukan dengan cara yang benar.

Materi mengenai CTPS, penggunaan masker, dan New Normal disajikan dalam satu kesatuan Video Learning yang menarik bagi siswa SD sebagai sasaran pengabdian. Video Learning yang disajikan bersifat interaktif dengan menyisipkan pertanyaan di tengah dan di akhir video agar mampu menstimulus siswa melakukan sesuatu. Perbedaan Video Learning tersebut dengan video lain yang sudah ada adalah:

a. Konten Video Learning mengenai New Normal beserta protokol kesehatan 5M, disajikan secara lengkap dari awal sampai akhir. Lengkap dengan penjelasan masing-masing kegiatan.

b. Memberikan logika sains pada kegiatan CTPS dan Memakai Masker. Kegiatan CTPS dekat dengan sains Kimia, menggunakan konsep cara kerja sabun. Sedangkan kegiatan memakai masker terkait dengan konsep sains fisika yaitu proses penyaringan.

\section{Pembuatan Materi Edukasi}

Pembuatan materi edukasi diawali dengan membuat storyboard yang nantinya akan dikembangkan menjadi video edukasi. Adapun tangkapan layar video edukasi kegiatan pengabdian ditampilkan pada Gambar 2 . 

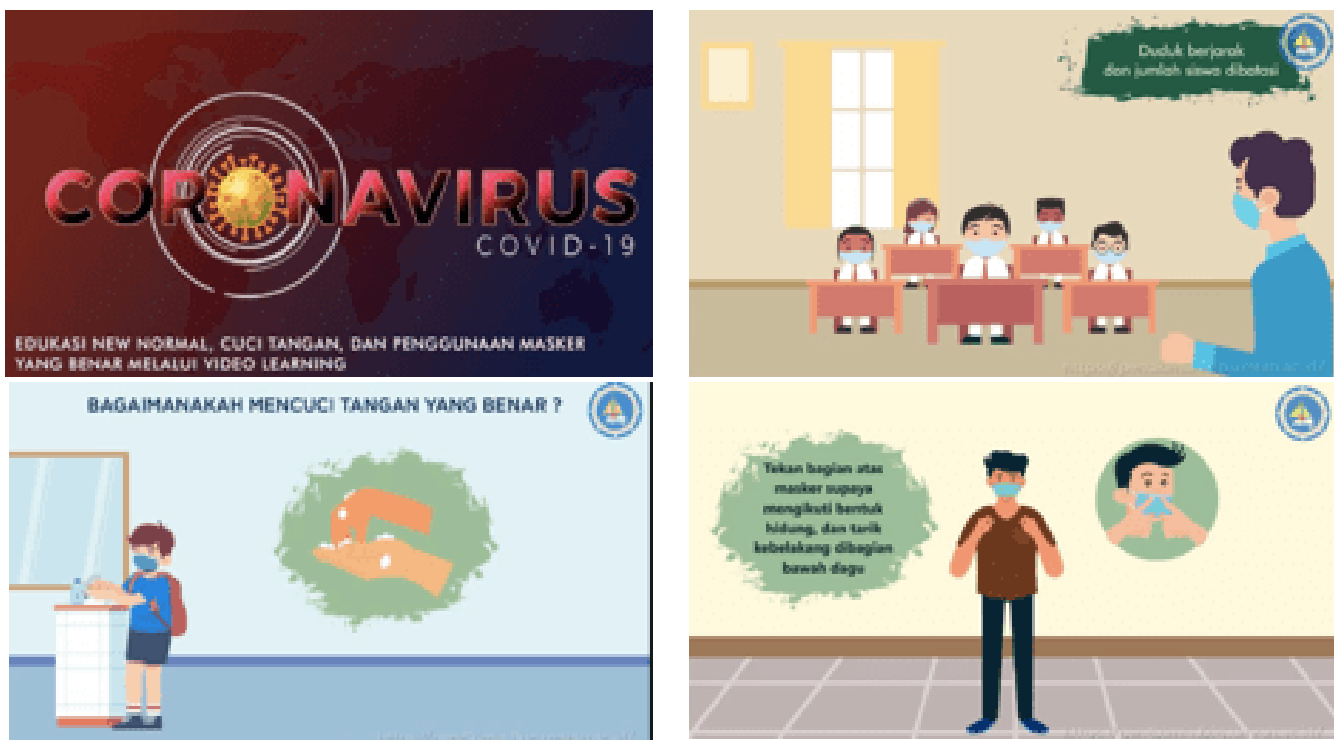

Gambar 2. Tangkapan layar video edukasi kegiatan pengabdian

\section{Edukasi kebiasaan New Normal di sekolah}

Kegiatan pengabdian dilakukan bersama dengan tim mahasiswa. Pada saat pembukaan, Kepala Sekolah SD Negeri 001 Telok Sebong Haryanto, S.Pd. SD., memberikan kata sambutan. Selanjutnya kata sambutan oleh ketua pelaksana PKMUP yaitu Inelda Yulita, S.Pd., M.Pd. Harapan dari kegiatan ini yaitu agar semua civitas dapat memahami dan menerapkan kebiasaan New Normal dengan senang hati. Kegiatan lebih pada mengedukasi civitas sekolah untuk memahami alasan mengapa harus CTPS dan bagaimana cara memakai masker yang benar.

Kegiatan edukasi dimulai dengan pemutaran Video Learning terkait tema pengabdian. Isi atau materi pada video disajikan dengan desain visual yang menarik, menambahkan backsound music pada video, dan memberikan effect pada video, sehingga membuat peserta terkhusus siswa antusias mengikuti kegiatan sampai selesai. Selain memutarkan video, materi diperkuat dengan pembahasan yang lebih detail mengenai New Normal, Penggunaan Masker Yang Benar, dan Cuci Tangan Pakai Sabun (CTPS), yang dilakukan persesi.

Materi tentang New Normal selain membahas kebiasaan baru dalam kehidupan pada masa pandemi, juga mengaitkan dengan sudut pandang agama, di mana semua kejadian tidak lepas dari kehendak Allah SWT, maka Allah SWT jugalah yang akan menjadi penolong umat manusia, sebagaimana dikutip dari Al quran surat Ath Taubah ayat 51. Sedangkan materi CTPS, disampaikan dengan menjelaskan secara ilmiah mengapa mencuci tangan tidak cukup dengan air saja. Sabun sangat berperan penting sebagai pelaku atraksi ganda saat sabun menghancurkan virus yang menempel di tangan. Begitu juga dengan materi menggunakan masker yang benar, dijelaskan secara ilmiah, di mana konsep memakai masker dianalogikan dengan alat penyaring debu. Makin rapat porinya, maka semakin banyak debu yang tersaring. Selain itu pada materi ini disampaikan juga jenis-jenis masker yang bisa digunakan. Diharapkan semua civitas yang hadir dapat membuat keputusan dalam memakai masker yang benar.

Diakhir sesi dilakukan praktik CTPS serta penggunaan masker dengan benar yang dibimbing oleh tim PKMUP. Semua peserta kegiatan melakukan praktik cuci tangan pakai sabun yang telah disediakan oleh tim mahasiswa. Satu-persatu maju mempraktekkan CTPS yang benar. Jika ada yang salah, maka tim mahasiswa akan memberikan contoh dengan mempraktikkan teknik yang benar. 

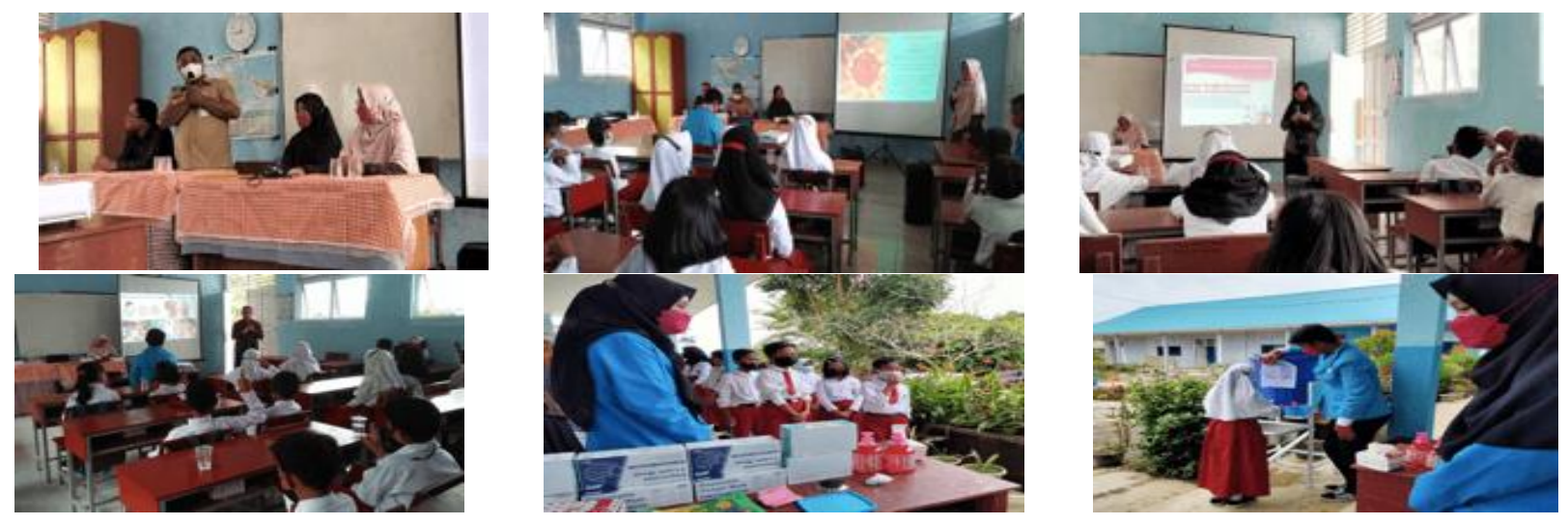

Gambar 3. Dokumentasi kegiatan edukasi New Normal, CTPS, dan penggunaan masker

di Sekolah SD Negeri 001 Telok Sebong

Di dalam kegiatan pengabdian ini dilakukan evaluasi terhadap pengetahuan dan pemahaman peserta setelah kegiatan edukasi selesai dilaksanakan, yakni dengan evaluasi berupa kuesioner terbuka. Isi dari kuesioner berisi pertanyaan tentang (1) protokol kesehatan yang harus dilakukan saat New Normal, (2) bagaimana cara penggunaan masker yang baik dan benar, (3) bagaimana cara mencuci tangan yang baik dan benar, (4) bagaimana menghindari Covid-19 dengan mobilitas, (5) alasan menjauhi kerumunan saat beraktivitas di luar rumah. Berikut dijabarkan hasil dari evaluasi kegiatan edukasi:

\section{Protokol Kesehatan Saat New Normal}

Pertanyaan pertama kuesioner adalah sehubungan dengan protokol kesehatan saat New Normal. Berdasarkan pengisian kuesioner pertanyaan pertama oleh peserta kegiatan edukasi diperoleh hasil sebagaimana ditampilkan pada Gambar 4.

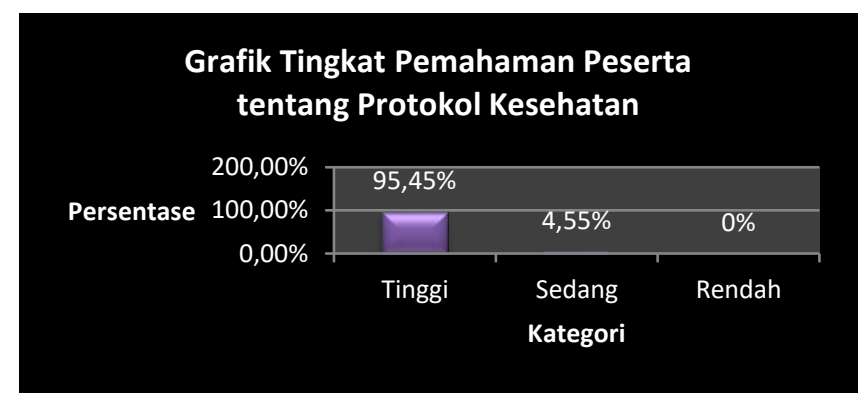

Gambar 4. Grafik tingkat pemahaman peserta tentang protokol kesehatan

Berdasarkan Gambar 4 diperoleh hasil bahwa tingkat pemahaman peserta tentang protokol kesehatan berturut-turut adalah kategori "tinggi" sebesar 94,95\% (21 peserta), kategori "sedang" sebesar 4,55\% (1 peserta), dan kategori "rendah" sebesar 0\% (0 peserta). Persentase terbesar tingkat pemahaman peserta tentang protokol kesehatan terdapat pada kategori "tinggi" yaitu sebesar 94,95\%. Ini artinya bahwa hampir seluruh peserta kegiatan edukasi memahami protokol kesehatan 5M yang ditetapkan pemerintah saat New Normal pada pandemi Covid-19. Adapun protokol kesehatan 5M yaitu menjaga jarak, memakai masker, mengurangi mobilitas, mencuci tangan, dan menjauhi kerumunan. 
Protokol kesehatan 5M harus dilakukan oleh setiap orang guna memutus penyebaran Covid-19. Semua pihak bertanggung jawab, baik pemerintah, swasta, masyarakat, lembaga keagamaan, tokoh agama, penegak hukum, media sosial, maupun media elektronik harus bersinergis. Begitupun dengan warga sekolah, agar juga dapat mematuhi peraturan dan imbauan pemerintah rangka memutus mata rantai penyebaran Covid-19. Sebagaimana yang dilakukan oleh Susilowati et al. (2020) dalam pengabdian masyarakat tentang sosialisasi protokol kesehatan menghadapi Covid-19. Pemerintah, dan warga masyarakat saling membantu, mendukung, serta mengingatkan untuk melawan Covid-19.

Protokol Kesehatan saat pandemi Covid-19 yakni menjaga jarak, memakai masker, mengurangi mobilitas, menjauhi kerumunan, dan CTPS. Diharapkan warga sekolah mengetahui kebiasaan New Normal dan dapat menerapkan dalam keseharian di sekolah. Hal ini seiring dengan kegiatan pengabdian oleh Nurhadi et al. (2020) yang mana melakukan kegiatan edukasi pencegahan Covid-19 melalui media poster untuk meningkatkan pengetahuan, pemahaman, dan kesadaran tentang pencegahan Covid-19 kepada Masyarakat Desa Karyamekar.

\section{Penggunaan Masker yang Baik dan Benar}

Pertanyaan kedua kuesioner adalah sehubungan dengan bagaimana cara penggunaan masker yang baik dan benar. Berdasarkan pengisian kuesioner pertanyaan kedua oleh peserta kegiatan edukasi diperoleh hasil sebagaimana ditampilkan pada Gambar 5.

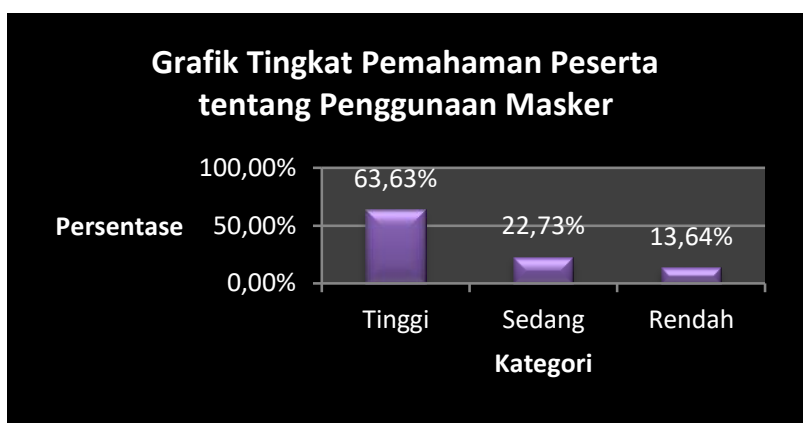

Gambar 5. Grafik tingkat pemahaman peserta tentang penggunaan masker

Berdasarkan Gambar 5 diperoleh hasil bahwa tingkat pemahaman peserta tentang penggunaan masker berturut-turut adalah kategori "tinggi" sebesar 63,63\% (14 peserta), kategori "sedang" sebesar 22,73\% (5 peserta), dan kategori "rendah" sebesar 13,64\% (3 peserta). Persentase terbesar tingkat pemahaman peserta tentang penggunaan masker terdapat pada kategori "tinggi" yaitu sebesar 63,63\%. Ini artinya lebih dari setengah peserta kegiatan edukasi memahami penggunaan masker yang baik dan benar, yakni dengan cara menutup hidung, mulut, dan dagu dengan masker. Pada kategori "sedang" peserta menjawab cara penggunaan masker yang baik dan benar adalah dengan hanya menutup hidung dan mulut saja. Sisanya pada kategori "rendah" jawaban peserta tidak berhubungan dengan cara penggunaan masker yang baik dan benar, yakni ada yang menjawab membuka tali masker, menekan hidung, dan memakai masker 3 lapis.

Penggunaan masker yang baik dan benar dapat membatasi penyebaran Covid-19 yang merupakan bagian dari rangkaian komprehensif pencegahan dan pengendalian. Hal ini seiring dengan kegiatan pengabdian yang dilakukan oleh Nuraeni et al. (2020) yang melakukan sosialisasi penggunaan dan pembagian masker di Kota Tasikmalaya dan kabupaten Tasikmalaya untuk pencegahan Covid-19. Setiap orang diwajibkan menggunakan masker ketika berada di tempat umum karena banyaknya ancaman Covid-19. Masker dapat digunakan untuk melindungi diri orang yang sehat saat berkontak dengan orang terinfeksi untuk mencegah penularan lebih lanjut. WHO merekomendasikan pemakaian masker menyeluruh di semua fasilitas bagi setiap 
orang, baik itu tenaga kesehatan ataupun masyarakat umum terlepas dari kegiatan yang dilakukan (WHO, 2020).

Ada banyak sekali jenis masker yang bisa digunakan. Ada 4 jenis masker yang bisa digunakan untuk mencegah Covid-19, yaitu masker bedah 2 lapis, masker bedah 3 lapis, masker N95, dan masker kain. Meski masker kain bukanlah masker yang ideal dan tidak seefektif masker bedah atau masker N95 dalam mencegah COVID-19, namun jika digunakan dengan benar, masker kain masih jauh lebih baik daripada tidak menggunakan masker sama sekali (Bangun et al., 2020). Penggunaan masker yang benar dapat mencegah seseorang tertular COVID-19 (Rohim \& Wicaksono, 2021). Namun, harus dipahami bahwa masker tidak dapat melindungi orang sehat dari risiko tertular virus (Acute \& Syndrome, 2020).

Penggunaan masker apa pun tidak berpengaruh pada efisiensi filtrasi atau kinerja penyegelannya. Jika tidak digunakan dalam kombinasi dengan tindakan pencegahan lainnya, dampaknya akan minimal (Silva, 2020). Selain itu, peran pemerintah sebagai pengambil keputusan tentunya sangat penting dalam mencegah penyebaran Covid-19. Khusus untuk penggunaan masker kain, disarankan untuk selalu memperkuat kerja sama antara pemerintah pusat dan daerah serta tenaga kesehatan dalam pendisiplinan penggunaan masker kain bagi masyarakat yang sehat untuk mencegah penyebaran Covid-19 (Putri, 2021).

\section{Mencuci Tangan yang Baik dan Benar}

Pertanyaan ketiga kuesioner adalah sehubungan dengan cara mencuci tangan yang baik dan benar. Berdasarkan pengisian kuesioner pertanyaan ketiga oleh peserta kegiatan edukasi diperoleh hasil sebagaimana ditampilkan pada Gambar 6.

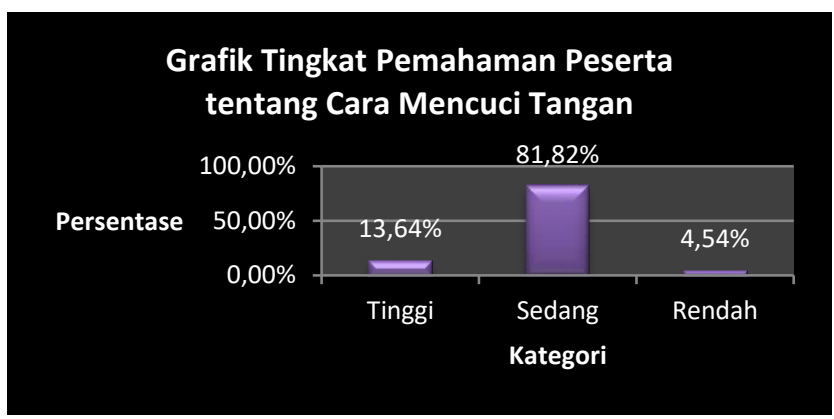

Gambar 6. Grafik tingkat pemahaman peserta tentang cara mencuci tangan

Berdasarkan Gambar 6 diperoleh hasil bahwa tingkat pemahaman peserta tentang cara mencuci tangan yang baik dan benar berturut-turut adalah kategori "tinggi" sebesar 13,64\% (3 peserta), kategori "sedang" sebesar 81,82\% (18 peserta), dan kategori "rendah" sebesar 4,54\% (1 peserta). Persentase terbesar tingkat pemahaman peserta tentang cara mencuci tangan yang baik dan benar terdapat pada kategori "sedang" sebesar $81,82 \%$. Peserta kegiatan edukasi yang hampir seluruhnya merupakan siswa SD bisa saja mengalami kesulitan untuk menyampaikan jawaban dalam bentuk tulisan. Pada prakteknya keseluruhan peserta sudah mampu mempraktekkan cara mencuci tangan yang baik dan benar yakni mencuci tangan pakai sabun kemudian menggosok punggung telapak tangan dan jari secara bergantian, dan terakhir membilasnya dengan air mengalir hingga bersih.

CTPS adalah teknik dasar yang paling penting untuk mencegah dan mengendalikan penyebaran virus. CTPS secara teratur dapat mengurangi diare dan penyakit pernapasan. CTPS lebih efektif dalam mencegah penyebaran virus daripada mencuci tangan hanya dengan air (Purwandari et al., 2013). Menurut Departemen Kesehatan RI (2009), lima waktu terpenting untuk CTPS adalah sebelum dan sesudah makan, setelah bermain, sebelum menyusui atau memberi makan bayi/anak, setelah dari toilet atau buang air besar, dan memasak atau 
menyiapkan makanan. Faktor pendukung pelaksanaan CTPS adalah adanya pengetahuan dan sikap yang baik terhadap CTPS, dan faktor penghambat CTPS adalah ketersediaan fasilitas air bersih (Mustikawati, 2017).

\section{Mobilitas}

Pertanyaan keempat kuesioner adalah sehubungan dengan bagaimana cara menghindari penyebaran Covid-19 dengan mengurangi mobilitas. Berdasarkan pengisian kuesioner pertanyaan keempat oleh peserta kegiatan edukasi diperoleh hasil sebagaimana ditampilkan pada Gambar 7.

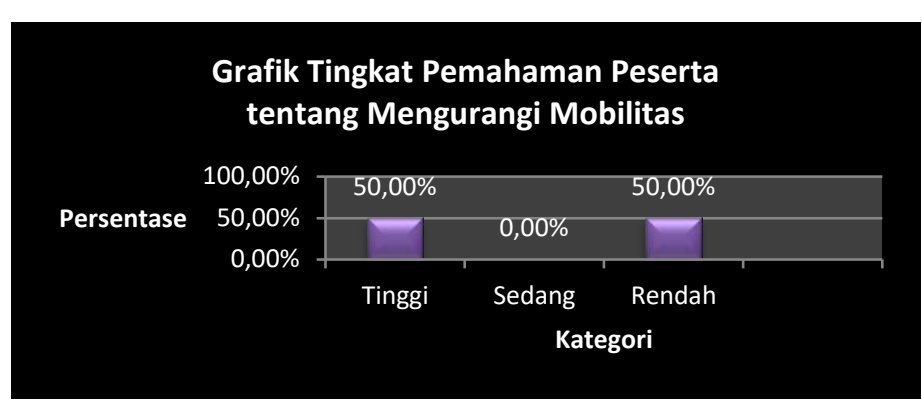

Gambar 7. Grafik tingkat pemahaman peserta tentang mobilitas

Berdasarkan Gambar 7 diperoleh hasil bahwa tingkat pemahaman peserta tentang mengurangi mobilitas adalah kategori "tinggi" sebesar 50,00\% (11 peserta) dan kategori "rendah" sebesar 50,00\% (11 peserta). Persentase kategori "tinggi" dan persentase kategori "rendah" bernilai sama. Setengah dari peserta kegiatan edukasi memiliki tingkat pemahaman dengan kategori "tinggi" dan setengahnya lagi memiliki tingkat pemahaman dengan kategori "rendah". Peserta dengan tingkat pemahaman kategori "tinggi" memahami dengan baik bagaimana cara menghindari penyebaran Covid-19 dengan mengurangi mobilitas yakni dengan tidak bepergian keluar rumah kecuali untuk hal penting atau mendesak. Sedangkan peserta dengan tingkat pemahaman kategori "rendah" kurang memahami dengan baik bagaimana cara menghindari penyebaran Covid-19 dengan mengurangi mobilitas. Hal ini bisa disebabkan karena mobilitas merupakan istilah yang baru bagi peserta kegiatan edukasi yang hampir seluruhnya adalah siswa SD.

Mengurangi mobilitas merupakan salah satu protokol kesehatan saat New Normal. Cara menghindari penyebaran Covid-19 dengan mengurangi mobilitas yaitu dengan tidak bepergian keluar rumah jika tidak urusan penting atau mendesak, tidak berkumpul di luar rumah, tidak jalan-jalan, dan sebagainya. Pemberlakuan WFH, WFO, dan belajar dari rumah merupakan beberapa contoh penerapan aturan untuk mengurangi mobilitas di luar rumah.

\section{Menjauhi Kerumunan}

Pertanyaan kelima kuesioner adalah sehubungan dengan alasan kenapa saat beraktivitas di luar rumah kita diminta untuk menjauhi kerumunan. Berdasarkan pengisian kuesioner pertanyaan kelima oleh peserta kegiatan edukasi diperoleh hasil sebagaimana ditampilkan pada Gambar 8. 


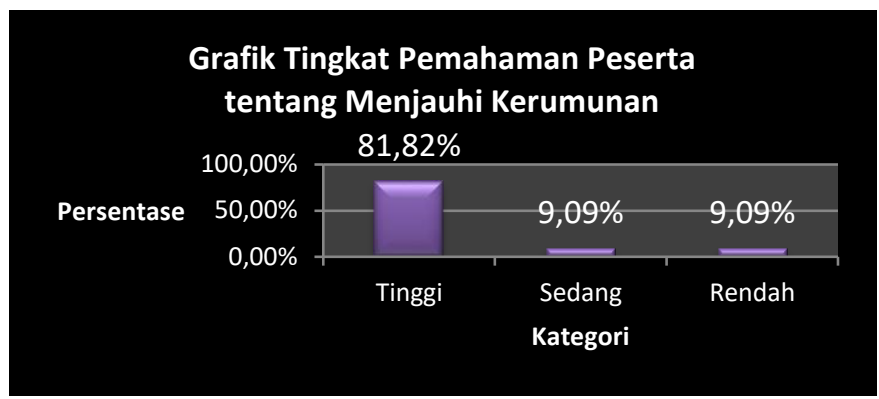

Gambar 8. Grafik tingkat pemahaman peserta tentang menjauhi kerumunan

Berdasarkan Gambar 8 diperoleh hasil bahwa tingkat pemahaman peserta tentang menjauhi kerumunan adalah kategori "tinggi" sebesar $81,82 \%$ (20 peserta), kategori "sedang" dan kategori "rendah" masing-masing sebesar 9,09\% (2 peserta). Persentase terbesar tingkat pemahaman peserta tentang menjauhi kerumunan terdapat pada kategori "tinggi" yaitu sebesar $81,82 \%$. Ini artinya bahwa hampir keseluruhan peserta kegiatan edukasi memahami alasan kenapa kita harus menjauhi kerumunan saat beraktivitas di luar rumah yaitu agar terhindar dari penyebaran Covid-19.

Menjauhi kerumunan merupakan salah satu protokol kesehatan saat New Normal. Apabila makin banyak dan sering kita berkomunikasi langsung dengan orang banyak, maka kemungkinan kita terinfeksi Covid-19 juga makin tinggi. Oleh sebab itu kita perlu waspada dan selalu mematuhi protokol kesehatan menjauhi kerumunan.

\section{Kesimpulan}

Kegiatan Edukasi New Normal, CTPS, dan Penggunaan Masker Melalui Video Learning di Lingkungan Sekolah SD Negeri 001 Teluk Sebong Kabupaten Bintan berjalan dengan lancar dan tanpa hambatan serta respons civitas sekolah yang antusias. Kegiatan ini memberikan manfaat bagi civitas sekolah khususnya bagi siswa SD. Peserta kegiatan edukasi telah memahami situasi pandemi Covid-19, protokol kesehatan 5M saat diberlakukannya New Normal, cara penggunaan masker yang baik dan benar, serta cara CTPS yang baik dan benar. Berdasarkan lima pertanyaan yang diberikan tingkat pemahaman tertinggi peserta kegiatan edukasi yaitu pada pertanyaan pertama tentang protokol kesehatan 5M (94,95\%). Video Learning kegiatan edukasi diberikan kepada pihak sekolah agar dapat dimanfaatkan dalam menyambut sistem pembelajaran tatap muka. Penyajian Video Learning kepada civitas sekolah sebagai pengingat untuk selalu melakukan pencegahan terhadap penyebaran virus Covid-19. Pada sistem penyajian Video Learning ini diserahkan kepada pihak sekolah.

\section{Saran}

Kegiatan ini diharapkan bisa dilaksanakan secara berkelanjutan dan diperlukan monitoring secara berkala dengan jangkauan yang lebih luas dalam rangka mencegah penyebaran virus Covid-19. Penambahan fasilitas CTPS di sekolah juga diperlukan agar memudahkan civitas sekolah, khususnya siswa untuk selalu mempraktekkan CTPS dengan baik dan benar.

\section{Ucapan Terima Kasih}

Penulis mengucapkan syukur Alhamdulillah kepada Allah SWT yang telah memberikan rahmat dan hidayah-Nya sehingga segala sesuatunya selalu diberikan kelancaran. Tidak lupa pula penulis ucapkan terima 
kasih kepada civitas sekolah SD Negeri 001 Teluk Sebong selaku mitra yang telah menyukseskan kegiatan pengabdian. Terima kasih juga kepada LP3M UMRAH yang telah memberikan dukungan moral dan dana terhadap kegiatan pengabdian ini.

\section{Referensi}

Acute, S., \& Syndrome, R. (2020). Recommendations recomendações recommendations from the Brazilian society of nephrology regarding the use of cloth face coverings. by chronic kidney patients, 9-11.

Bangun, H. A., Sinaga, L. R. V., \& Manurung, J. (2020). PKM Sosialisasi penggunaan masker medis dan kain dalam upaya pencegahan Covid -19 di UPTD di Puskesmas Namohalu Esiwa Kabupaten Nias Utara. Jurnal Pengabdian Masyarakat Universitas Sari Mutiara Indonesia, 2(1), 32-39.

Departemen Kesehatan RI. (2009). Panduan penyelenggaraan cuci tangan pakai sabun sedunia (HCTPS). Kementerian Kesehatan RI.

Mustikawati, I. S. (2017). Perilaku cuci tangan pakai sabun studi kualitatif pada ibu-ibu di Kampung Nelayan Muara Angke Jakarta Utara; Studi Kualitatif. Arsip Kesehatan Masyarakat, 2(1), 115-125.

Kemenkes RI. (2020). Pedoman pencegahan dan pengendalian coronavirus disease (covid-19). Kementerian Kesehatan RI.

Lestari, L., Putranto, A. T., Dewi, R., Said, M. T. I., Mekka, S., \& Pratama, W. A. P. (2020). Penyuluhan tentang budaya cuci tangan pada masa pandemi Covid-19 dengan metode 6 langkah kepada pasien poliklinik di Rumah Sakit Bhakti Mulia Jakarta Barat. Jurnal Pengabdian Masyarakat (PKM) Kreasi Mahasiswa Mnajemen, 1(2), 170-175.

Lubis, N., Saputra, M. H., Al-Baasith, R. I., Setiadi, S., \& Oktaviani, S. (2020). Gerakan desa sadar bahaya covid 19: pengabdian pada masyarakat desa Cilawu Kabupaten Garut. Jurnal Kreativitas Pengabdian Kepada Masyarakat, 3(2), 480-494.

Nugroho, S. H. P., Umma, N., Lianawati, N., Purnomo, H., \& Kusumawati, G. R. (2020). Kesiapan adaptasi kebiasaan baru pencegahan penularan Covid-19. Jurnal Pengabdian Kepada Masyarakat LPPMUniversitas Muhammadiyah Tasikmalaya. ABDIMAS UMTAS: Jurnal Pengabdian Kepada Masyarakat, $4(1), 578-583$.

Nuraeni, I., Bachtiar, R. A., Karimah, I., Hadiningsih, N., Setiawati, D., \& Saragih, M. (2020). Pencegahan covid-19 melalui sosialisasi penggunaan dan pembagian masker di Kota Tasikmalaya dan Kabupaten Tasikmalaya. Jurnal Pengabdian Masyarakat dan Inovasi, 1(2), 578-583.

Nurhadi, Z. F., Parentza, H., Munandar, A., Rachman, D., \& Muldan, Y. D. (2020). Strategi komunikasi dan edukasi pencegahan covid-19 melalui media poster. Jurnal Pengabdian Kepada Masyarakat LPPMUniversitas Muhammadiyah Tasikmalaya, 4(1), 537-543.

Purwandari, R., Ardiana, A., \& Wantiyah. (2013). Hubungan antara perilaku mencuci tangan dengan insiden diare pada anak usia sekolah di kabupaten Jember. Jurnal Keperawatan, 122-130. 
Putri, S. L. (2021). Studi literatur: efektivitas penggunaan masker kain dalam pencegahan transmisi Covid-19. Jurnal Kesehatan Manarang, 5(nomor khusus), 09-17.

Rohim, A., \& Wicaksono, A. P. (2021). Edukasi pemakaian masker sebagai upaya penegakan protokol kesehatan di era pandemi covid -19 pada masyarakat kampung Kebonso RT 02 RW 02, Pulisen, Boyolali. Intelektiva: Jurnal Ekonomi, Sosial \& Humaniora, 2(9), 58-63.

Silva, F. (2020). Use of homemade cloth masks in the face of the pandemic by COVID-19 in Use of homemade cloth masks in the face of the pandemic by COVID-19 in Brazil.

Sudijono, A. (2010). Pengantar statistik pendidikan. Rajawali Press.

Susilowati, D., Widiyasari, D., Mayangsari, S., Ridhansyah, A., Fandi, Pramesti, S., ... Thoyalisy, R. (2020). Pengabdian masyarakat melalui sosialisasi protokol kesehatan menghadapi pandemi Covid-19. Jurnal pembelajaran pemberdayaan masyarakat, JP2M, 1(4), 300-304.

Jacobis, I. J., Palilingan, R. A., \& Bawiling, N. S. (2021). Persepsi dan sikap masyarakat dalam menghadapi kebiasaan baru (new normal) saat pandemi corona virus (COVID-19) di Desa Ponompiaan Kecamatan Dumoga. UNIMA: Jurnal Kesehatan Masyarakat, 2(3), 1-8.

WHO. (2020). Penggunaan masker dalam konteks Covid-19. 